Current Research: Ceramic Production and Distribution during the Formative Caddo Period: A Stylistic and Provenance Investigation of the Arkansas River Valley

Shawn Lambert

Mississippi State University

Follow this and additional works at: https://scholarworks.sfasu.edu/ita

Part of the American Material Culture Commons, Archaeological Anthropology Commons, Environmental Studies Commons, Other American Studies Commons, Other Arts and Humanities Commons, Other History of Art, Architecture, and Archaeology Commons, and the United States History Commons

Tell us how this article helped you.

This Article is brought to you for free and open access by the Center for Regional Heritage Research at SFA ScholarWorks. It has been accepted for inclusion in Index of Texas Archaeology: Open Access Gray Literature from the Lone Star State by an authorized editor of SFA ScholarWorks. For more information, please contact cdsscholarworks@sfasu.edu. 


\section{Current Research: Ceramic Production and Distribution during the Formative Caddo Period: A Stylistic and Provenance Investigation of the Arkansas River Valley \\ Creative Commons License \\ (c) (1) (9)}

This work is licensed under a Creative Commons Attribution-NonCommercial 4.0 International License 


\title{
Current Research: Ceramic Production and Distribution during the Formative Caddo Period: A Stylistic and Provenance Investigation of the Arkansas River Valley
}

\author{
Shawn Lambert \\ University of Oklahoma
}

The Formative Caddo Period (A.D. 850-1100) of eastern Oklahoma was marked by dramatic material and ritual changes, culminating in the construction of aggregated villages and ceremonial centers (Girard et al. 2014). Formative Caddo groups are notable for their highly complex and ritually-charged ceramic vessels that were unlike anything archeologists have seen in the American Southeast (Bell 1984). Tracing the rapid development and spread of this early fine ware assemblage across a variety of social, ritual, and mortuary contexts is key to understanding the shared religious and ritual traditions of the pre-Columbian Arkansas River valley and surrounding Coastal Plain drainages. Yet despite nearly 60 years of archeological research, insight is still lacking into the organization of Formative Caddo ceramic production and the mechanics of exchange between the northern and southern Caddo areas.

While archeologists have shown Formative Caddo fine wares were locally produced in the Red River valley and surrounding Coastal Plain drainages (Girard et al. 2014:27-28), they have assumed that Caddo people in Arkansas River valley and Ozark Plateau locally produced them (Bell 1984). However, they are not recovered from the same contexts across both Caddo areas. Formative Caddo pottery is commonly found in both domestic and ritual contexts at Coastal Plain sites (Bell et al. 1969; Bohannon 1973; Burton 1970; Rohrbaugh 1972, 1973; Wyckoff $1965,1967,1968)$ but are restricted to ritual contexts at ceremonial centers on the Ozark Plateau (Bell 1972; Brown 1996; Schambach 1982, 1988, 1990, 1993). The ritual contexts in which Formative Caddo ceramics are recovered are also quite different. At Coastal Plain ceremonial centers, such as George C. Davis in Texas and Crenshaw in Arkansas, Formative Caddo ceramics were deposited in off-mound, on-mound, and mortuary contexts. Yet, at ceremonial centers of the
Ozark Plateau, such as Spiro, Harlan, and Brackett in Oklahoma, Formative Caddo ceramics were deposited exclusively in mortuary contexts. The marked contrast between Formative Caddo pottery use and deposition between the northern and southern ceremonial centers provides insight into the development of Formative Caddo ritual practices and traditions. It suggests there may be fundamental differences in the ritual programs of the northern and southern Caddo areas.

To examine the emergence and spread of these traditions, I am conducting a regional-scale study of the production and distribution of Formative Caddo pottery in the northern and southern Caddo areas. This project has two major components. First, it involves the analysis of clay chemical composition of 264 fine ware sherds from five ceremonial sites in the Arkansas River Basin (Figure 1). I applied for and was granted a National Science Foundation Dissertation Improvement Grant to pay for Instrumental Neutron Activation Analysis (INAA) on these sherds. Once the INAA is completed, I will compare the Arkansas Basin results with previously generated elemental sourcing data from the Coastal Plain region (Perttula and Selden 2013). Secondly, this project involves a stylistic analysis (i.e., following Plog's [1980] and Early's [2012] research on style) of the forms and designs on 199 fine ware vessels to understand their overall design grammar and structure. The sites to be studied include Spiro, Harlan, Norman, Reed, and Brackett in the Arkansas River drainage and Crenshaw, Boxed Springs, George C. Davis, and Mounds Plantation in the Gulf Coastal Plain region (Figure 2). I hypothesize that either (1) Formative Caddo fine wares found in the Arkansas River basin were imported from the Red River valley and surrounding Coastal Plain drainages, where they were fabricated, or (2) Formative Caddo vessels were manufactured in the Arkansas River Basin, but intended use was restricted for mortuary 


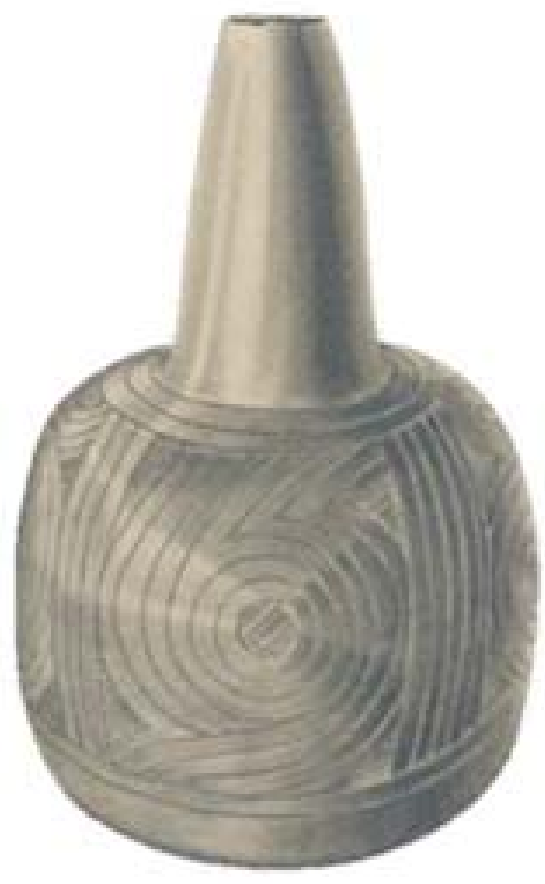

a

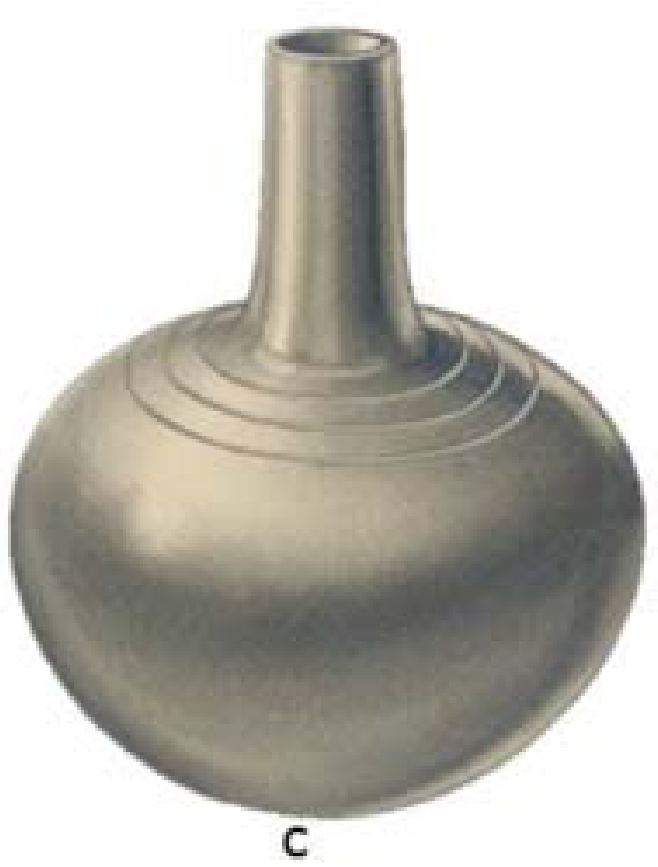

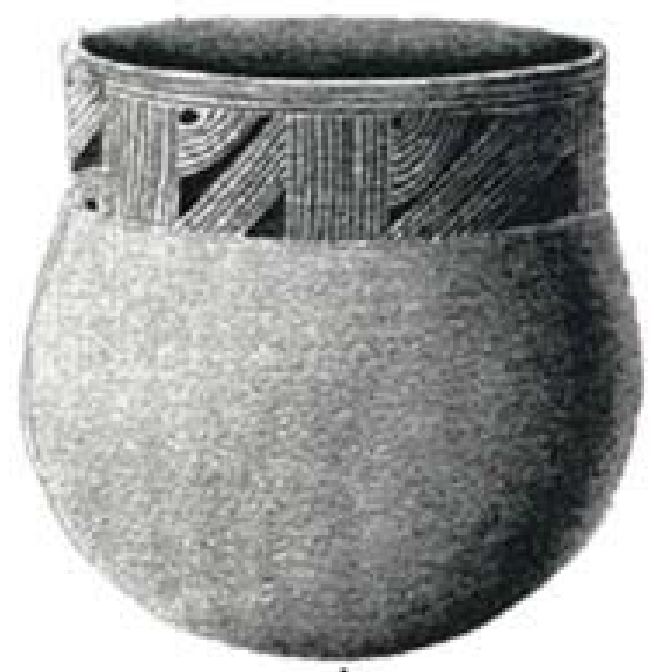

b

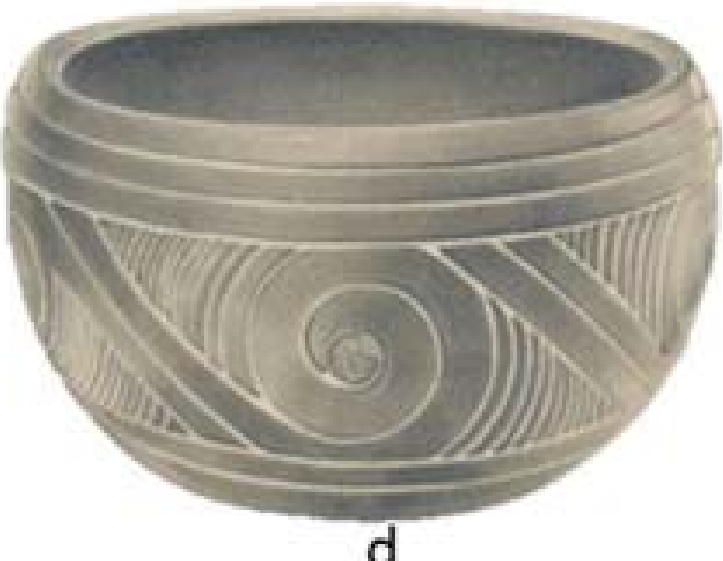

Figure 1. Formative Caddo ceramic types selected for study: a, Spiro Engraved; b, Holly Fine Engraved; c, Hickory Engraved; and d, Crockett Curvilinear Incised. 


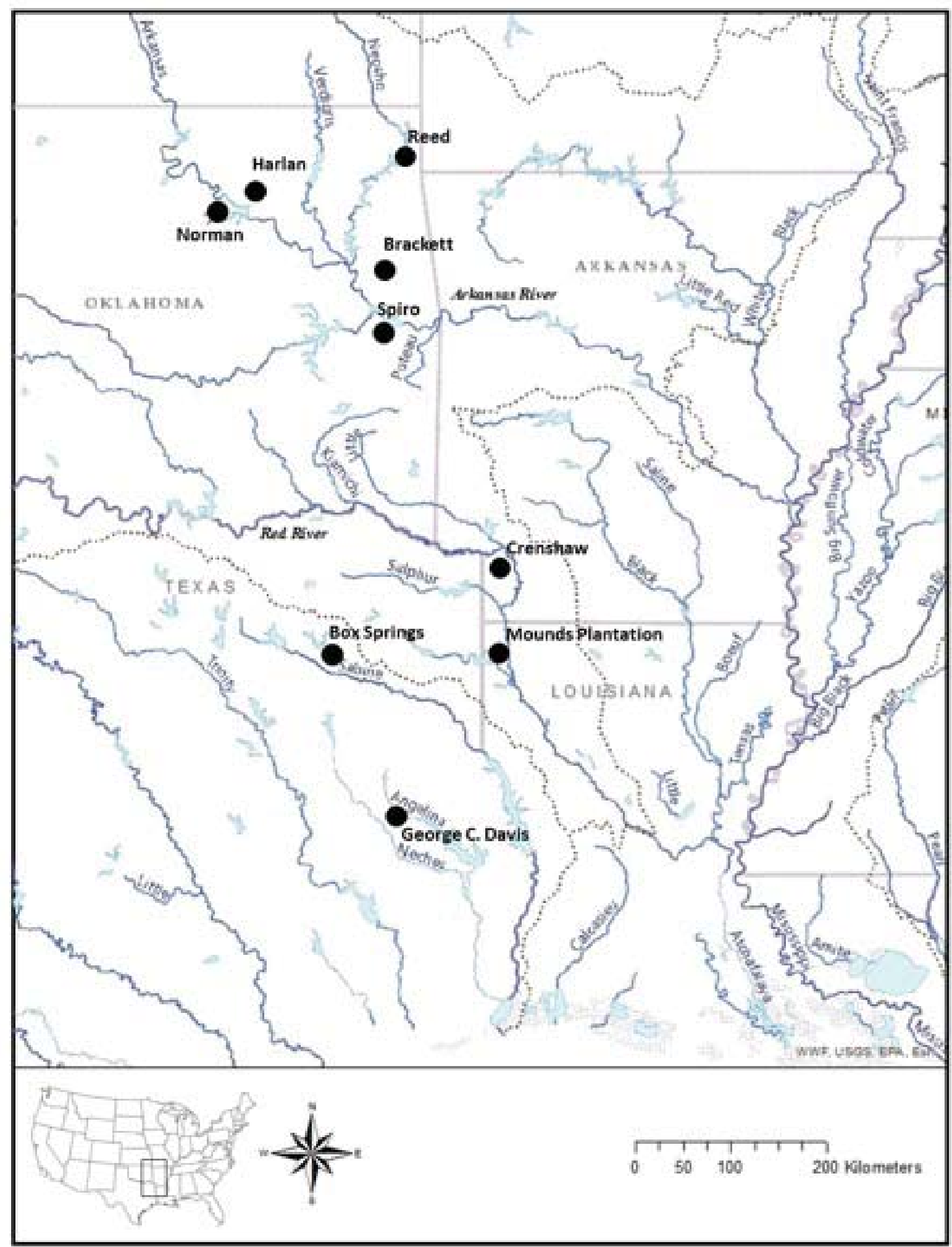

Figure 2. Sites selected for research in eastern Oklahoma and southern Caddo area. 
purposes. Whether the first or second hypothesis is supported by this research, it will determine whether this is a single or separate communities of practice, and will have major implications for how we view the integration of these communities and the origins of Caddo ritual traditions.

\section{Ritual Mode of Production, Distribution, and Communities of Practice}

\section{If Formative Caddo fine wares were}

used strictly for mortuary purposes at every major ceremonial center in the northern Caddo area, who made them and what prompted their exchange? Caddo archeologists have not assumed a significant degree of craft specialization during the Formative Caddo period (Girard et al. 2014) because traditionally the idea of specialization for ritual use and wide-scale distribution is thought to be present in more developed or ranked societies (Van Keuren et al. 1997). In fact, craft specialization in societies with an emerging organizational complexity have been primarily attributed to economic or political factors, such as risk avoidance, population increase, or aspiring charismatic leaders (Bell 1984; Blitz 1991; Netting 1990; Price and Brown 1985; Renfrew 1982; Wills 1992; Wilson 1999). An alternative to these models is the "ritual mode of production" in small scale or middle-ranged societies (Spielmann 2002, 2008). This approach argues that intensified craft production and distribution in smallscale groups is a social response to an amplified demand by individuals and communal ceremonial obligations (Spielmann 2002:195). Intensified craft specialization in small scale groups is not so much about meeting the demands of subsistence. Instead, it is about meeting the demand for "socially valued goods" that were used for ritual purposes. Central to this premise is an emphasis on the community in which these socially valued goods were produced and then distributed "as they fulfill ritual obligations and create and sustain social relations" (Spielmann 2002:196-167).

Sassaman (2004:39), when examining the origins and spread of pottery in native North America, reasoned that ritual demand for pottery for ceremonial and mortuary purposes "may have led to increased demand for vessels in general." Saunders and Wrenn
(2014) studied the ritual modes of production and distribution of a Late Archaic type called Orange pottery in northeast Florida. Although much more data was needed, their findings suggested that this early pottery may have been produced by potters strictly for ritual use and distribution across different drainages. Moreover, Miller (2014) investigated the ritual economy of bladelets from Hopewell earthworks. Miller's findings suggested that only a few craft specialists may have been responsible for the moderate production and distribution of the stone blades.

Another major thrust of this research is to theoretically frame it with communities of practice to achieve a more nuanced understanding of how and why different Formative Caddo groups emerged and interacted with one another. The theory of communities of practice offers a way to recognize past communities' capacity to be different, and at the same time be socially and ritually connected through a system of social networks that were constituted and maintained by the production and distribution of specific objects (Joyce 2012). A community of practice is defined as a group of experienced producers and apprentices who participate in the learned production of a shared material enterprise (Minar 2001a, 2001b; Stark 2006; Van Keuran 2006). A regional stylistic and INAA study by itself may not necessarily imply more fine-grained scales of organization of pottery production. However, it would seem logical that if one of the primary goals of one or more community of potters was to produce formative fine wares in quantities so that they could be exchanged with northern Caddo groups who utilized them in significantly different ways, then this comparative study would effectively demonstrate a broad but necessary understanding of the organization of pottery production and distribution by emphasizing separate communities of practice.

Motivated by this research, I ask whether northern or southern Caddo communities of potters might have been involved in the production and distribution of Formative Caddo pottery for mortuary use at Arkansas Basin ceremonial centers. Once production locales are determined through INAA, it may show that this mode of ritual production and distribution was an integral way in which Formative Caddo groups created ceremonial obligations and maintained long- 
distance relationships with one another. To understand distinct Formative Caddo communities of practice in time and space, one must first have a clear understanding of the social and ritual contexts of ceramic production and distribution (Fenn et al. 2006). Archeologists have a clearer understanding of the organization of pottery production and distribution in the southern Caddo area (Perttula 2013a; Selden 2013; Selden et al. 2014), but still lack the insight necessary to understand pottery production and distribution in the northern Caddo area. Before we can truly recognize more fine-grained scales of pottery production and distribution in the Caddo area, such as household and community scales of production (e.g., Abbott 2009), we first need to untangle the roles of ritual production and distribution by considering the cultural region in its entirety (Renfrew 2001).

\section{Concluding Remarks}

By integrating multiple lines of ceramic evidence and considering these finer-scale data in regional contexts, this study will shed light into the intersections of production, distribution, exchange, and ideological dynamics during the Formative Caddo period. Archeologists have not only shown the major archeological implications by highlighting contextual differences in ceramic use and the ritual motivations for production and exchange in a region with small scale societies (Wallis 2014; Wilson 1999), but they have also made known the power of using INAA as a salient method to understand the organization of production and distribution that emphasized unique perspectives of social interactions and ritual practices (Levine et al. 2015; Wallis et al. 2010). This project thus seeks to understand Caddo ritual motivations of formative fine ware production through a detailed INAA and stylistic study that will distinguish which communities of potters produced them across the region. In other words, I will be able to show how the same pottery types mattered differently among separate groups of the Caddo. Whether northern or southern groups produced formative fine wares, this study will add to our current understanding of early Caddo development. Finally, this research will have major implication for how we interpret emerging Caddo ritual practices and traditions, and potentially point to a much larger regional exchange between separate groups of the Caddo much earlier than is currently accepted.

\section{References Cited}

Abbott, David R.

2009 Extensive and Long-Term Specialization: Hohokam Ceramic Production in the Phoenix Basin, Arizona. American Antiquity 74(3):531557.

Bell, Robert E.

1972 The Harlan Site, Ck-6, A Prehistoric Mound Center in Cherokee County, Eastern Oklahoma. Memoir No. 2. Oklahoma Anthropological Society, Oklahoma City.

Bell, Robert E. (editor)

1984 Prehistory of Oklahoma. Academic Press, Orlando.

Bell, Robert E., Gayles S. Lacy Jr., Margaret T. Joscher, and Joe C. Allen

1969 The Robinson-Solesbee Site, HS-9, A Fulton Aspect Occupation, Robert S. Kerr Reservoir, Eastern Oklahoma. Archaeological Survey Site Report No. 15. Oklahoma River Basin Survey, University of Oklahoma Research Institute,Norman.

Blitz, John H.

1991 Community Organization in a Small-Scale Mississippian Society: Implications for Chiefdom Formation. Ph.D. Dissertation, City University of New York, Ann Arbor.

Bohannon, Charles F.

1973 Excavations at the Mineral Springs Site, Howard County, Arkansas. Research Series No. 5. Arkansas Archeological Survey, Fayetteville.

Brown, James A.

1996 The Spiro Ceremonial Center: The Archaeology of Arkansas Valley Caddoan Culture in Eastern Oklahoma. Memoirs No. 29, 2 Vols. Museum of Anthropology, University of Michigan, Ann Arbor. 
Burton, Susan S.

1970 The Hugo Dam Site, Ch-112 Choctaw County, Southeast Oklahoma. Archaeological Site Report No. 16. Oklahoma River Basin Survey, University of Oklahoma Research Institute, Norman.

Early, Ann M.

2012 Form and Structure in Prehistoric Caddo Pottery Design. In The Archaeology of the Caddo, edited by Timothy K. Perttula and Chester P. Walker. pp 26-46. University of Nebraska Press, Lincoln and London.

Fenn, Thomas R., Barbara J. Mills, and Maren Hopkins 2006 The Social Contexts of Glaze-Painted Pottery in the Pueblo Southwest: A Synthesis. In The Social Life of Pots: Glaze Wares and Cultural Dynamics in the Southwest AD 1250-1680, edited by Judith A Habicht-Mauche, Suzanne L. Eckert, and Deborah L. Huntley, pp. 60-85. University of Arizona Press, Tucson.

Girard, Jeffrey S., Timothy K. Perttula, and Mary Beth Trubitt

2014 Caddo Connections: Cultural Interactions within and Beyond the Caddo World. Rowman and Littlefield, Lanham, Maryland.

Joyce, Rosemary A.

2012 Thinking About Pottery Production as Community Practice. In Potters and Communities of Practice: Glaze Paint and Polychrome Pottery in the American Southwest, A.D. 1250-1700, edited by Linda S. Cordell and Judith A. Habicht-Mauche, pp. 149-153. University of Arizona Press, Tucson.

Levine, Marc N., Lane F. Fargher, Leslie G. Cecil, and Jamie E. Forde

2015 Polychrome Pottery Economics and Ritual Life in Postclassic Oaxaca, Mexico. Latin American Antiquity 26(3):319-340.

Miller, Logan G.

2014 Ritual, Craft, and Economy in Ohio Hopewell: An Examination of Two Earthworks on the Little Miami River. Ph.D. Dissertation. Ohio State University, Columbus.
Minar, Jill C.

2001a Material Culture and Identification of Prehistoric Cultural Groups. In Fleeting Identities: Material Culture and Perishability, edited by Penelope B. Drooker, pp. 94-113. Center for Archaeological Investigations, Southern Illinois University, Carbondale.

2001b Motor Skills and the Learning Process: The Conservation of Cordage Final Twist Direction in Communities of Practice. Journal of Anthropological Research 57(4):381-405.

Netting, Robert

1990 Population, Permanent Agriculture, and Politics: Unpacking the Evolutionary Portmanteau. In The Evolution of Political Systems, edited by Stewart Upham, pp. 21-61. Cambridge University Press, Cambridge.

Perttula, Timothy K.

2013 Caddo Ceramics in East Texas. Bulletin of the Texas Archeological Society 84:181-212.

Perttula, Timothy K. and Robert Z. Selden, Jr. 2013 Bibliography on Woodland and Caddo Instrumental Neutron Activation Analysis and Petrographic Analysis Studies in East Texas, Northwest Louisiana, Eastern Oklahoma, and Southwest Arkansas. Caddo Archeology Journal 23:93-104.

Plog, Stephen

1980 Stylistic Variation in Prehistoric Ceramics. Cambridge University Press, Cambridge.

Price, Douglas T. and James A. Brown

1985 Aspects of Hunter-Gatherer Complexity. In Prehistoric Hunter-Gatherers: The Emergence of Cultural Complexity, edited by Douglas T. Price and James A. Brown, pp. 3-20. Academic Press, Orlando.

Rohrbaugh, Charles L.

1972 Hugo Reservoir 2. Archaeological Site Report No. 23. Oklahoma River Basin Survey, University of Oklahoma Research Institute, Norman. 
1973 Hugo Reservoir 3. Archaeological Site Report No. 24. Oklahoma River Basin Survey, University of Oklahoma Research Institute, Norman.

Renfrew, Colin

1982 Polity and Power: Interaction, Intensification, and Exploitation. In An Island Polity: The Archaeology of Exploitation in Melos, edited by Colin Renfrew and M. Wagstaff, pp. 264-290. Cambridge University Press, Cambridge.

2001 Production and Consumption in a Sacred Economy: The Material Correlates of High Devotional Expression at Chaco Canyon. American Antiquity 66(1):14-25.

Sassaman, Kenneth E.

2004 Common Origins and Divergent Histories in the Early Pottery Traditions of the American Southeast. In Early Pottery: Technology, Function, Style, and Interaction in the Lower Southeast, edited by Rebecca Saunders and Christopher T. Hays, pp. 23-39. University of Alabama Press, Tuscaloosa.

Saunders, Rebecca and Margaret K. Wrenn

2014 Crafting Orange Pottery in Early Florida. In New Histories of Pre-Columbian Florida, edited by Neil J. Wallis and Asa R. Randall, pp. 183-202. University of Florida Press, Gainesville.

Schambach, Frank F.

1982 The Archaeology of the Great Bend Region in Arkansas. In Contributions to the Archeology of the Great Bend Region, edited by Frank F. Schambach and Frank Rackerby, pp. 1-11. Research Series No. 22. Arkansas Archeological Survey, Fayetteville.

1988 The Archaeology of Oklahoma. Quarterly Review of Archeology 9(4):5-9.

1990 The Place of Spiro in Southeastern Prehistory: Is It Caddoan or Mississippian?. Southeastern Archaeology 9(1):67-69.
1993 Some New Interpretations of Spiroan Culture History. In Archaeology of Eastern North America: Papers in Honor of Stephen Williams, edited by James B. Stoltman, pp. 187-230. Archaeological Report 25. Mississippi Department of Archives and History, Jackson.

Selden, Robert Z. Jr.

2013 Consilience: Radiocarbon, Instrumental Neutron Activation Analysis, and Litigation in the Ancestral Caddo Region. Ph.D. Dissertation, Department of Anthropology, Texas A\&M University, College Station.

Selden, Robert Z. Jr., Timothy K. Perttula, and David L. Carlson

2014 INAA and the Provenance of Shell-Tempered Sherds in the Ancestral Caddo Region. Journal of Archaeological Science 47:113-120.

Spielmann, Katherine A.

2002 Craft Specialization, and the Ritual Mode of Production in Small-Scale Societies. American Anthropologist 104(1):195-207.

2008 Crafting the Sacred: Ritual Places and Paraphernalia in Small-Scale Societies. Research in Economic Anthropology 27:37-72.

Stark, Miriam T.

2006 Glaze Ware Technology, the Social Lives of Pots, and Communities of Practice in the Late Prehistoric Southwest. In The Social Life of Pots: Glaze Wares and Cultural Dynamics in the Southwest, AD 1250-1680, edited by Judith A. Habicht-Mauche, Suzanne L. Eckert, and Deborah L. Huntley, pp. 17-33. University of Arizona Press, Tucson.

Van Keuran, Scott

2006 Decorating Glaze-Painted Pottery in East-Central Arizona. In The Social Life of Pots: Glaze Wares and Cultural Dynamics in the Southwest, AD 1250-1680, edited by Judith A. Habicht-Mauche, Susanne L. Eckert, and Deborah L. Huntley, pp. 86-104. The University of Arizona Press, Tucson. 
Van Keuran, Scott, Susan L. Stinson, and David R. Abbott

1997 Specialized Production of Hohokam Plain Ware Ceramics in the Lower Salt River Valley. Kiva 63(2):155-175.

Wallis, Neil J.

2014 Ritualized Practices of the Suwannee Valley Culture in North Florida. In New Histories of PreColumbian Florida, edited by Neil J. Wallis and Asa R. Randall, pp. 243-261. University of Florida Press, Gainesville.

Wallis, Neil J., Matthew T. Boulanger, Jeffrey R. Ferguson, and Michael D. Glascock

2010 Woodland Period Ceramic Provenance and the Exchange of Swift Creek Complicated Stamped Vessel in the Southern United States. Journal of Archaeological Science 37:2598-2611.

Wills, Wirt H.

1992 Plant Cultivation and the Evolution of Risk-Prone Economies in the Prehistoric American Southwest. In Transitions to Agriculture in Prehistory, edited by Anne Birgitte Gebauer and T. Douglas Price, pp. 153-176. Prehistory Press, Madison.

Wilson, Gregory D.

1999 The Production and Consumption of Mississippian Fineware in the American Bottom. Southeastern Archaeology 18(2):98-109.
Wyckoff, Don G.

1965 The Hughes, Lamas Branch, and Callaham Sites, McCurtain County, Southeast Oklahoma. Archaeological Site Report No. 4. Oklahoma River Basin Survey Project, University of Oklahoma Research Institute, Norman.

1967 The Archaeological Sequence in the Broken Bow Reservoir Area McCurtain County, Oklahoma. Oklahoma River Basin Survey Report No. 6. University of Oklahoma Research Institute, Norman.

1968 The Beaver Site and Archaeology of the Broken Bow Reservoir Area McCurtain County, Oklahoma. Archaeological Site Report No. 9. Oklahoma River Basin Survey, University of Oklahoma Research Institute, Norman. 